\title{
Disaster resilience: what it is and how it can engender a meaningful change in development policy
}

Keating, A. ${ }^{1}$, Campbell, K. ${ }^{2}$, Mechler, R. ${ }^{1}$, Magnuszewski, P. ${ }^{1}$, Mochizuki, J. ${ }^{1}$, Liu, W. ${ }^{1}$, Szoenyi, M. McQuistan, $\mathrm{C}^{4}$.

${ }^{1}$ International Institute for Applied Systems Analysis, Laxenburg, Austria

${ }^{2}$ University of Pennsylvania, Wharton Center for Risk and Decision Processes, Philadelphia

${ }^{3}$ Zurich Insurance Company LTD, Zurich

${ }^{4}$ Practical Action, Climate Change and Disaster Risk Reduction, United Kingdom

\section{Abstract}

Disasters pose a growing threat to sustainable development. Disaster risk management efforts have largely failed to arrest the underlying drivers of growing risk globally: uncontrolled urbanization and proliferation of assets in hazardous areas. Resilience provides an opportunity to confront the socialecological foundations of risk and development; yet it has been vaguely conceptualized, without offering a concrete approach to operationalization. We propose a conceptualization of disaster resilience centred on wellbeing: 'The ability of a system, community or society to pursue its social, ecological and economic development objectives, while managing its disaster risk over time in a mutually reinforcing way.' We present a conceptual framework for understanding the interconnections between disasters and development, and outline how it is being operationalized in practice.

Keywords: Disasters, Resilience, Development, Policy, Systems.

\section{Introduction}

Flooding is the number one source of disaster loss and damage worldwide; globally the number of people exposed to floods each year is increasing at a higher rate than population growth (Miller et al., 2008; UNISDR, 2011). This is largely due to high migration into high risk areas, particularly coastal zones (CRED, 2015; Gencer, 2013; de Sherbinin et al., 2007). Kundzewicz et al. (2014) mapped the geographic centres of large floods over the period 1985-2010, demonstrating that many large floods hit key loci of socio-economic development in South Asia, East Asia and the Pacific, where more than 90 per cent of flood-exposed people live. Unprecedented mobilization of populations and an increasingly globalized economy mean that economic opportunity is one of the factors drawing people to high risk areas, particularly on the outskirts or hazardous areas of cities (Hallegatte, 2011; Fernandez \& Sanahuj, 2012; Braun \& Assheuer, 2011; UNISDR, 2011; UNISDR, 2015). Low- and lower-middle-income countries have a larger proportion of exposed population, and their exposure is growing. 
Recently, the 2015 Sendai Framework for Disaster Risk Reduction 2015-2030 (United Nations, 2015), and the Global Assessment Report 2015 (UNISDR, 2015) have emphasized the 'unnaturalness' of 'natural disasters'; disasters are an outcome of trends in the location of people and assets, and economic, environmental and land use policies, rather than a series of exogenous and unpredictable misfortunes. This situation is familiar right across the globe - from the growth in highly flood exposed slums in Dhaka, Bangladesh (Braun \& Assheuer, 2011), to the promotion of risk-blind tourism development in Fiji (Bernard \& Cook, 2012), and to the attraction of development in scenic but hazardous riverside and coastal areas in both developed and developing countries (Gencer, 2013; Dohmen, 2014). Current efforts in disaster risk management (DRM) have largely failed to devise effective measures to tackle this growing risk, largely because it is a systemic problem outside of their institutional reach. These documents represent the state of the art of DRM, and reveal a shifting paradigm in this field. This paper explains why this shift in thinking is necessary and proposes a novel way to conceptualize and operationalize a holistic approach for DRM and development by focusing on the resilience of development goals and human wellbeing.

Urgency for this shift is enhanced due to climate change: one of the first impacts of climate change to be detected is expected to be the increase in the frequency and severity of extreme weather events (Banholzer et al., 2014; IPCC, 2012; van Aalst, 2006). Slower onset climate change impacts are also expected to be felt most profoundly by the most vulnerable, and thereby exacerbate their vulnerability to disasters (Adger \& Brooks, 2003).

There is an increasing body of work on what disaster resilience is or is not (e.g., see NRC, 2012; UNISDR, 2011; ADB, 2013; DFID, 2011; IFRC, 2012; IPCC, 2012; Twigg, 2009) ${ }^{1}$. However the theoretical underpinnings of disaster resilience remain ephemeral. Likewise the operationalization of the concept remains a significant challenge. In practice it is difficult to distinguish between DRM and enhancing disaster resilience; this situation is partially driven by the broad ways in which disaster resilience is defined, which we review. Resilience is at risk of being a new buzzword for business-asusual. The challenge for disaster resilience is to break away from the narrow and static approach which has characterized actions to protect development gains from disasters. The concept has the potential to help bridge the deep divisions between the DRM and development fields, and this paper provides a conceptual framework for the critical first step of understanding the interactions between them.

\footnotetext{
${ }^{1}$ Some definitions of resilience are positivist in the sense that a system can be 'resilient' regardless of the values placed on that system functioning. For example, poverty could be said to be a powerfully resilient system. In this paper we take a normative approach to disaster resilience, arguing that it is a 'good' thing for communities. We do this because this is over whelming the approach dominating the global discussion on disaster and climate resilience at the time of writing.
} 
We propose an approach which identifies and builds on the strengths in the current thinking on disaster resilience and brings these out explicitly. Our definition is centred on the sustainability of development gains and wellbeing in the presence of shocks, rather than on managing shocks per se. When then present a conceptual framework which visualizes the definition, explicitly bringing out the interconnections between disaster risk, DRM, and development trajectories. This framework and associated methodological approach is being applied in field work over the coming years via a participatory process, and is moving our understanding of disaster resilience forward via testing, refining, empirical validation, and synthesis of key lessons learnt. By building on the systems thinking roots of resilience, our approach helps identify and act upon the critical relationships and intervention points which drive long-term wellbeing outcomes in the face of disaster risk.

First we explain the key interrelationships which dynamically connect prevailing development trajectories and growing disaster risk: namely increased exposure driven by an economic liberalization model of development creating profound incentives for the proliferation of people and assets in high risk areas. We then explore how current practice in DRM also influences human, social, environmental and economic development and disaster risk - both positively and negatively. Next we summarize the discussion regarding definitions of disaster resilience and present our definition. This perspective is captured in our conceptual framework, based on systems analysis, which serves to visualize the complex interaction inherent in the disaster resilience system and identify entry- points for tackling the gaps around operationalization. We show how the disaster resilience concept can be a useful bridge between the disasters and development fields that allows mutual understanding of interactions to facilitate a virtuous cycle leading to improved development outcomes and reductions in disaster burdens.

\section{Development and disasters are interconnected}

So-called 'natural' disasters ${ }^{2}$ have significant immediate and long-term impacts on development and wellbeing. They pose a profound threat to gains made in education, health, infrastructure, economic development and environmental sustainability worldwide. The frequency and severity of disasters have increased substantially and this trend is expected to continue (CRED, 2015; Gencer, 2013; IPCC 2012). In some low- and middle-income countries, national risk from disasters is not simply growing in proportion to economic growth, it is outpacing it. Efforts to reduce risk and prepare for events are often not keeping pace with the rate at which risk is increasing (UNISDR, 2011; UNISDR, 2015).

\footnotetext{
2 This paper is concerned primarily with humanitarian disasters caused by meteorological and geophysical events, so-called 'natural disasters' rather than man-made disasters such as terrorist attacks.
} 
Ironically, a key underlying driver behind the increasing risk of disasters threatening development gains globally are the very actions considered, at least within the dominant paradigm of neoliberal economics, to foster economic growth and development. Where economic necessity and/or the promise of economic opportunity is leading to uncontrolled urbanization (Fernandez and Sanahuj, 2012), risk-blind infrastructure investment (Bernard and Cook, 2013; Hallegatte 2011), and erosion of traditional livelihood systems (Adger et al., 2005), we are witnessing huge increases in people and assets relocating to hazardprone areas, particularly flood plains (CRED, 2015; IPCC, 2012; UNISDR, 2013; UNISDR, 2015).

\subsection{Disasters: a profound threat to development gains}

Globally the number of events which reach the level of disaster ${ }^{3}$, and the magnitude of their impacts, are increasing (UNISDR, 2013; UNISDR, 2015); consequently the threat to development gains is also increasing. Globally there has been partial success at reducing mortality from disasters, with the least success seen in low-income countries with weak governance (CRED, 2015). Impacts from disasters continue to be disproportionately borne by the poor and marginalized groups, both between and within countries (CRED, 2015; Neumayer \& Plümper, 2007).

The immediate devastation caused by natural disasters, called direct damage, includes mortality, morbidity, and destruction of critical assets such as housing, schools, hospitals, transport infrastructure, and businesses. The risk of experiencing this direct damage is now commonly understood as a function of hazard, exposure and vulnerability (UNISDR, 2009; IPCC, 2012). Hazard is the meteorological or geophysical phenomenon, exposure is the 'people, property, systems, or other elements present in the hazard zone' (UNISDR 2009), and vulnerability is the characteristics of people and assets which make them 'susceptible to the damaging effects of the hazard' as a function of its intensity from 0 (no damage or loss) to 1 (total loss) (UNISDR 2009). The direct damage caused by disasters can be ameliorated by crisis management during and directly following the hazard event.

Figure 1 shows how the factors influencing disaster risk (hazard ${ }^{4}$, exposure and vulnerability), and crisis preparedness, co-determine direct damage. The direct economic damages from disasters, typically estimated in terms of value of destroyed and damaged physical assets, are a relatively well-understood and quantified problem for development.

\footnotetext{
${ }^{3}$ UNISDR (2009) defines a disaster as 'A serious disruption of the functioning of a community or a society involving widespread human, material, economic or environmental losses and impacts, which exceeds the ability of the affected community or society to cope using its own resources.'

${ }^{4}$ Hazard here is refined to floods because flooding is the focus of our current work. However the theory is generalizable to other hazards.
} 


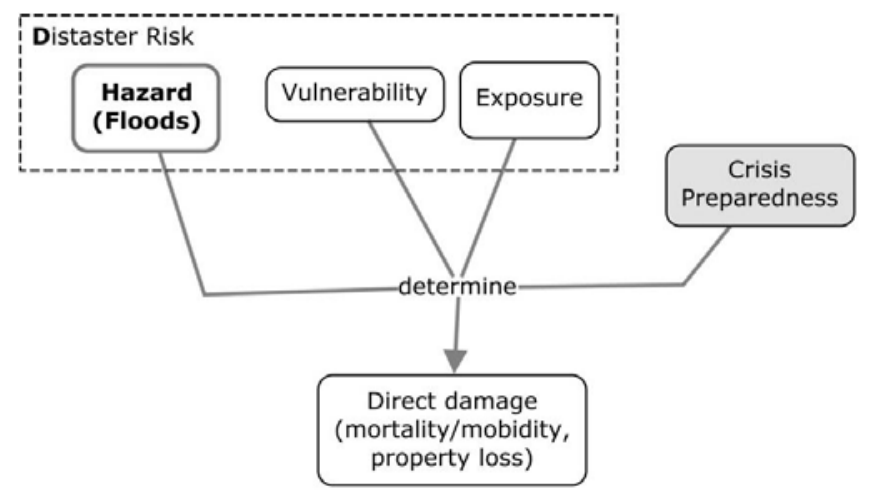

Figure 1: Factors influencing disaster risk and determinants of direct damage Source: Authors.

We focus now on the indirect or longer-term impacts, often called 'losses', that disasters can have (Figure 2). We know that disasters have significant impacts in the long term, however empirical support and analysis of these impacts are more challenging to undertake compared to direct effects (Mochizuki et al., 2015). When modelling the indirect impact of disasters using disaster statistics in order to estimate relationships, studies generally find very limited aggregate macroeconomic (national level) impacts of disasters in developed countries, but important regional economic and distributional effects (Okuyama, 2003). In developing countries, disasters have been found to lead to important adverse macroeconomic and developmental impacts and to affect the pace and nature of socioeconomic development (Mechler, 2004; Otero and Marti, 1995; Benson and Clay, 2004; ECLAC, 2003; Charveriat, 2000; Raddatz, 2007; Kellenberg and Mobarak, 2008; Hochrainer, 2009; Noy, 2009; Cavallo and Noy, 2009; IPCC, 2012). These analyses typically have low- to medium-confidence regarding the extent of the link between disasters and macroeconomic outcomes, possibly due to inherent limitations of economic indicators, such as GDP, lack of data availability and otherwise significant regional impacts being drowned out at the national scale (Mochizuki et al., 2015).

At the local level, where quantification exists, studies strongly indicate that disasters have long-term impacts on businesses, households and individuals, which vary across groups. More often than not, the poor suffer disproportionately due to the lack of financial and social safety nets and institutional representation (Morris et al., 2002; Cutter et al., 2006; Anttila-Hughes \& Hsiang, 2013).This is particularly devastating in developing countries, especially in pockets where repeated disasters erode the capacity to recover. In the worst circumstances, recurrent disasters can trap people and communities in a vicious cycle of poverty from which they cannot escape (Berhanu, 2011). For instance, disasters may result in poor and marginalized households adopting coping strategies which erode their long-term 
wellbeing, such as unsustainable environmental exploitation, taking children out of school, or selling productive assets (Heltberg et al., 2012; Hochrainer-Stiger et al., 2011) (Figure 2).

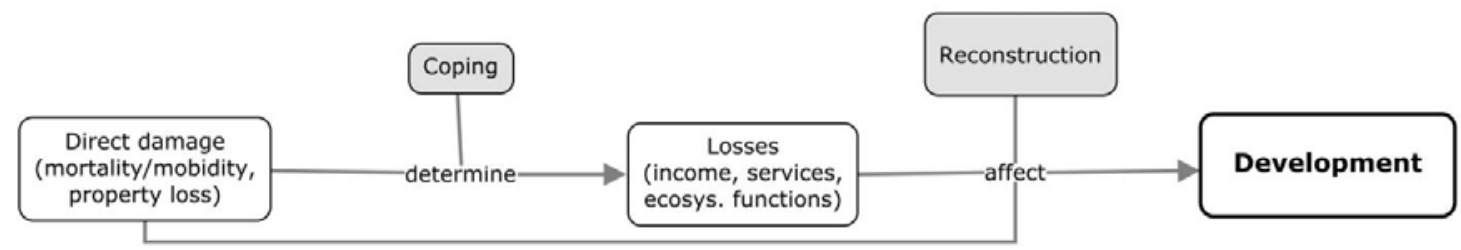

Figure 2: Direct damage and coping strategies co-determine indirect losses from disasters; direct damages, losses and reconstruction decisions all affect development Source: Authors.

Resources available for coping and reconstruction, combined with individual actions taken in pre- and post-disaster periods, determine how well an individual, household, firm or community respond to, cope with, and adapt to risks over-time. The lack of formal economic (amongst other) safety nets such as adequate government assistance, property and crop insurance, or availability of loans is a common feature found in developing countries due primarily to affordability issues, lack of insurance culture, and prohibitive transaction costs. In the absence of formal insurance, households and firms turn to 'informal' insurance such as kinship exchange of food and money. The availability of these informal arrangements, and their effectiveness, are strongly tied to resource endowments. Furthermore, informal risk sharing at the community level can have limited effectiveness for managing disasters if and when events are at a scale which affects the whole community, thereby wiping out sharing potential (Linnerooth-Bayer, 2008; Fafchamps and Lund, 2003; Townsend, 1994). At the level of government and NGO response assistance, we often find that the majority of response and recovery funds go to addressing direct impacts (ie rebuilding). Apart from being comparatively more difficult to assess, resource constraints mean that very little is left for addressing indirect effects after response and reconstruction efforts. Donors are also biased towards concrete and photographable rebuilding efforts, as opposed to the comparatively less visible amelioration of indirect effects (Kellet and Caravani, 2013).

\subsection{Development is driving the increase in disaster risk}

The type of development which dominates in a location also affects disaster risk, typically via three main channels: (1) by changing the absolute number/value, and/or the proportion, of assets and people located in high risk areas (see Figure 3); (2) by influencing physical and social vulnerability depending on different development outcomes (Figure 3); and (3) by influencing the capacity to undertake risk reduction, preparedness, response and recovery operations (Figure 4). These interactions should be 
contextualized within the higher level driver of increasing disaster risk - increasing frequency and severity of hazards induced by climate change (IPCC, 2012).

Development here is understood holistically, rather than taking a narrow proxy such as economic wealth or income. Following the Sustainable Livelihoods Framework (DFID, 1999), which is widely known and applied in the development sector, we characterize development based on the Five C's (five capitals or asset groups): human, social, natural, physical and financial (Figure 3).These complementary sources of capital influence people's wellbeing. From an analytical perspective, the Five Cs provide greater richness of data about a community's sources of risk and resilience (as we will see later) than any single metric.

Figure 3 shows a simplified relationship between development and factors of disaster risk (exposure and vulnerability) via changes in land use, infrastructure and assets in at-risk areas. Prevailing development trends in an area have a profound impact on disaster risk; for example, strong protection and regeneration of environmental assets for example, typically enhances flood provisioning ecosystem services. Unfortunately it is the case that a vision of development centred on economic growth - particularly manifested through economic liberalization, and structural adjustment programmes in the 1980s and 90s has dominated national and international policies. This development paradigm is resulting in an increase in disaster risk via the increase in urbanization (Bryceson, 2000; Gencer, 2013; Schipper and Pelling, 2006; Gerulis-Darcy, 2013) and incentives to situate assets in hazardous zones (Hallegatte, 2011). Particularly in developing countries, the regions which have been most attractive for investment and are subsequently experiencing rapid economic growth, are overwhelmingly in areas exposed to hazards, a major concern for global growth in disaster risk (UNISDR, 2013; UNISDR, 2015).

As of 2014, 54 per cent of the world's population was residing in urban areas, an increase from 30 per cent in 1950. By 2050 it is estimated that 66 per cent of the world's population will be living in urban areas. Accounting for population growth, this translates to an additional 2.5 billion people in urban areas, and 90 per cent of this increase will be in Asia and Africa (United Nations, 2014). Braun and Assheuer (2011) describe the high profile situation in Dhaka, Bangladesh, one of the most flood-prone countries on Earth. Rapid urbanization and population growth has seen an explosion of settlements in marginal, highly flood-exposed areas. These areas typically take the form of informal slum settlements, populated by the poorest Dhaka residents who lack security of tenure and economic capital. In Peru, economic growth and government services are concentrated in Lima; this attracts migrants from rural areas to settle in marginal and land-slide prone areas on the outskirts of Lima (Fernandez and Sanahuj, 2012; Gencer, 2013). Similar patterns have been observed globally (Gencer, 2013). While mega-cities such as Dhaka, Mumbai, Rio de Janeiro and Shanghai (de Sherbinin et al., 2007) are the focus of much attention, it should be noted that 
smaller cities and urban centres also play a significant part in this trend (Bull-Kamanga et al., 2003; Gencer, 2013; Fernandez \& Sanahuj, 2012).

Hallegatte (2011) points out that hazardous sites often provide comparative advantage for investment. For example, sites close to ports are important for export despite being exposed to storm surge. The UNISDR (2013) reports that the 'number of export oriented Special Economic Zones has expanded from 176 zones in 47 countries in 1986 to 3,500 zones in 130 countries in 2006.' Many of these zones of high economic growth are located in hazardous areas such as coasts and near major rivers (Hallegatte, 2011; UNISDR, 2013). Wamsler (2004, pg. 17) describes a 'global bidding process between cities, to attract investment' where competition for capital investment from multinational corporations sees cities down-bidding each other in terms of lowering environmental and risk regulations. Bernard and Cook (2013) describe how extensive flood buffering mangroves and old growth trees were removed to make way for major international hotel chains to establish an upscale tourist enclave in Fiji. This investment was actively encouraged by incentives including tax-free status for 20 years. Furthermore, the development attracted significant rural to urban migration, to service the influx of tourists. It is these people who now bare the brunt of losses associated with severe flooding, while at the same time being exposed to variations in the tourism industry.

A further way that certain types of development initiatives can inadvertently increase disaster risk via changes in land use, infrastructure and assets in at-risk areas, might be a decision to encourage the cultivation of a highly lucrative but climatically vulnerable cash crop. This choice may not only increases disaster risk, it can also erodes traditional livelihood diversification which may have supported communities to weather shocks. For example in Sri Lanka, increasing cultivation of tobacco on slopes has contributed to increasing landslide hazard(Zubair et al., 2006). Similarly in Nicaragua, Gerulis-Darcy (2013) explores how structural adjustment policies designed to foster agricultural exports have resulted in a shift from subsistence-based economies to cash cropping. This shift has resulted in the displacement off the most marginalized groups, who migrate to urban areas (exacerbating urbanization-driven risk there), or to areas which are ecologically fragile, previously provided disaster provisioning services, and/or are hazardous themselves. What we see here are complex interactions between economic policies, urbanization, and disaster risk. 


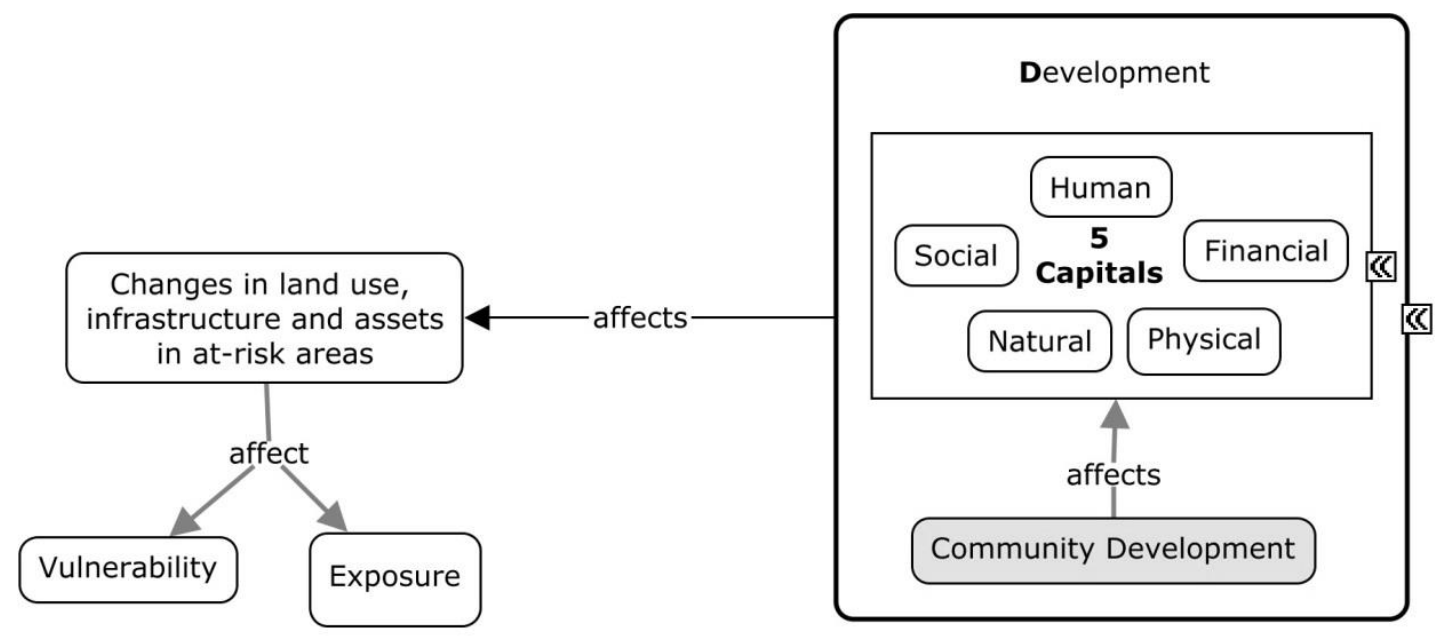

Figure 3: Development decisions affect land use in at-risk areas, which in turn affects vulnerability and exposure

\section{Source: Authors.}

Development not only impacts exposure, it also increases or decreases vulnerability based on the specifics of the development trends occurring, thereby contributing to increasing or reducing disaster risk. While exposure has been increasing, since 1990 overall vulnerability to disasters has been decreasing or stable across the globe - with some exceptions, noticeably in South Asia (UNISDR, 2011). The impact of variation in vulnerability when projecting impacts of disasters and climate change has been largely ignored, possibly because quantifying vulnerability is a significant challenge (IPCC, 2012; Mechler and Bouwer, 2014). The relationship between development decisions and vulnerability, and in turn disaster risk, provides a substantial opportunity to arrest the growth in disaster risk which is yet to be fully taken advantage of (Mechler and Bouwer, 2014).

More positively, development influences capacity to undertake $\mathrm{DRM}^{5}$ by providing the resources needed to undertake ex-ante and ex-post action in relation to disaster risk and disaster events. In cross-national analysis, development in human, social, and financial capitals is positively correlated with the development and execution of DRM planning (Figure 4) (UNISDR, 2011; Garschagen \& RomeroLankao, 2015). It is hypothesized that many (but not all) countries experiencing steady growth in GDP are

\footnotetext{
${ }^{5}$ The disaster risk management cycle relates to both ex-ante actions to reduce risk and prepare for events, and expost action to respond to and recover from events. Here we define this cycle as consisting of: prospective risk reduction (UNISDR, 2009) - actions to avoid the creation of more risk; corrective risk reduction (UNISDR, 2009) reducing risk to existing at-risk people and assets; crisis preparedness - preparation of people and assets for events; coping (Heltberg et al., 2012) - actions taken following an event to manage its consequences; and, reconstruction (as in recovery as defined by UNISDR, 2009) - actions following disaster to recover and rebuild assets and livelihoods.
} 
also experiencing increasing budgetary, institutional and governance capacity required to undertake DRM.

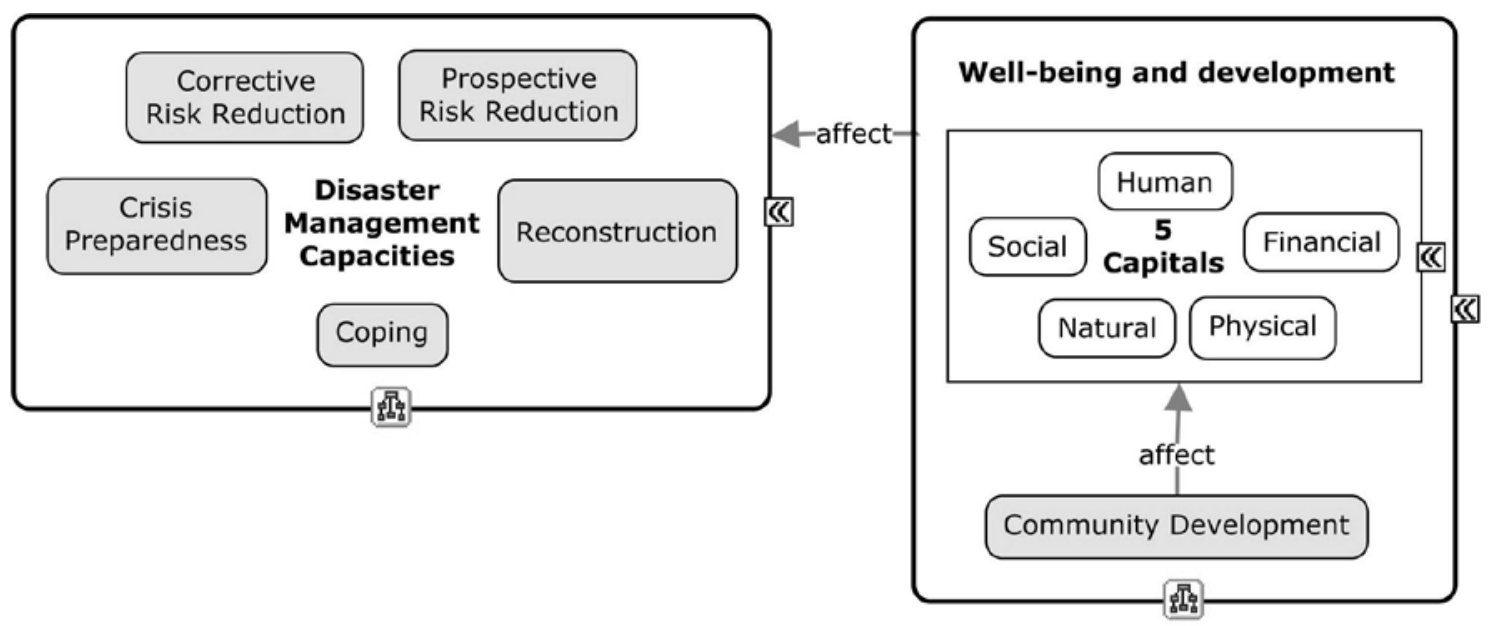

Figure 4: Development status influences disaster risk management capacity Source: Authors.

\subsection{More and better action needed to protect development gains}

Changes in land use, infrastructure, and assets which lead to increased disaster risk are undertaken because they afford (some groups) an advantage in terms of income generation or wellbeing more broadly. The evidence on rapidly increasing exposure indicates that this trade-off between development benefits and increased disaster risk is not being adequately managed. The Hyogo Framework for Action (United Nation, 2005) was designed to address increasing risk, and under its guidance countries have been successful at bringing down disaster mortality, in relative terms (UNISDR, 2013). This work addressing the symptom of disasters must continue, however a change in approach is needed because a review of the success of HFA initiatives shows that there has not been significant success in arresting the increasing loss and damage from disasters (UNISDR, 2015), which are driven by prevailing trends in urbanization and asset growth. Avenues for addressing this challenge are limited under the dominant operational environments of DRM and development.

These operational environments are subject to a number of features and structures which limit the capacity to address growing disaster risk. Numerous authors have explored the disaster risk management gap in development practice and urban planning (Schipper and Pelling, 2006; Bull-Kamanga et al., 2003; Wamsler, 2004). They find multiple constraints on the mainstreaming of disaster risk into government, community and international development decision-making. The political economy landscape is complex, with drivers including institutional and funding structures, prevailing attitudes about disaster risk being 
external, and colonial and historical legacies. Critically, the field identifies specific disincentives of the powerful to advance action to reduce risk, because the current state-of-affairs is beneficial for them. For example, Bull-Kamanga et al., (2003, pg. 200) state that "more powerful vested political and economic interests and the wealthier households are often protected from disasters. Politicians may even "benefit" from disasters, for example by being seen to respond when a disaster occurs, when they should have acted before it occurred to reduce the risk.”

This prevailing political economy is resulting in only a miniscule proportion of disaster related spending goes towards ex-ante action (Benson and Twigg, 2004). In practice there is a significant neglect of initiatives to reduce risk and prepare for disasters before they happen (ex-ante actions), rather than simply respond and attempt to recover (ex-post actions). Kellett and Caravani (2013, pg. 5) find that 'for every $\$ 100$ spent on development aid, just 40 cents has been invested in defending that aid from the impact of disaster'. From households to national and international bodies, people across the globe are found to be biased when it comes to reducing risk. Research has identified some broad drivers of ex-post versus exante action. These are (1) biased perceptions of the risk, (2) cognitive biases when it comes to dealing with low-probability and/or uncertain events, (3) budget and affordability concerns, and (4) political visibility effects (Kunreuther et al., 2013).

The dominance of ex-post response and recovery over ex-ante risk reduction, risk transfer/sharing, and preparedness occurs despite the presence of theory and supporting evidence, as laid out in the Hyogo Framework (UN, 2005) and UNISDR (2015), that disasters are not 'natural'. If disasters are not 'natural' or exogenous, then the experience of the hazard is mediated by exposure and vulnerability - namely prevailing development trends - which can be altered to alter risk. It also occurs despite the demonstrated cost-effectiveness of ex-ante actions. Foresight (2012) finds that the benefits of investment in ex-ante risk reduction outweighs costs in terms of damages avoided and losses reduced, by an average factor of four to one across a number of interventions and hazards (for further cost-effectiveness studies see Mechler et al., 2014; Kreibich and Thieken, 2007; Bubeck et al., 2012).

At the level of government and international assistance, several perverse incentives exist that contribute to the majority of resources going to ex-post response and recovery. Firstly, there is the continued perception of disasters as natural and unavoidable 'acts of God' among some politicians, planners and populations (Lavell and Maskrey, 2014; Cardona, 2003). Secondly, in regards to international aid, populations in donor countries like to see concrete outcomes from their aid dollars (Kellet and Caravani, 2013; Schipper and Pelling, 2006). Donor populations are also prone to compassion effect (van Aalst et al., 2013): when a disaster strikes, donor populations demand a substantial response to the immediate 
suffering. These and other influences mean that for official development assistance and international NGOs, response and recovery is far more achievable.

The third aspect identified is an internal political dimension. It is difficult to estimate and politically justify the expense of scarce resources on prevention for something perceived to be a rare occurrence. This makes the benefits of risk reduction largely invisible because they are what did not happen in a disaster (the unseen); response and relief on the other hand are politically positive because they are visible and demanded by people (van Aalst et al., 2013; Bull-Kamanga et al., 2003). Because populations are largely myopic about risk, there is not significant demand from the population on elected officials to invest public money in prevention over other, more immediate, public services. Further to this is the fact that disasters occur at the local level and hence the money can be targeting; when it comes to risk reduction on the other hand, governments are faced with multiple at-risk locations and multiple hazards while knowing that their limited budget could not protect everyone.

When risk reduction actions are undertaken (which also leads to changes in land use, see Figure 5), there is a general lack of integration of human, social and environmental factors in intervention design. Decisions are typically dominated by economic and physical considerations. For example, the impacts of embankments on riverine ecosystems are rarely seriously considered when the investment in embankments is decided (Sendzimir et al., 2008; Heine \& Pinter, 2012). Similarly, the practice of disaster impact assessment rarely includes impacts beyond loss of life counts, physical damage inventory and some estimates of impact on the formal economy (see for example the EM-DAT database, Guha-Sapir et al., n.d.; Mochizuki et al., 2015); so-called intangible impacts on social and environmental assets are only estimated on an ad-hoc basis, typically for large events in developed countries. Since disaster impact assessments are a key informant of disaster risk related decision-making, their narrow focus feeds back into these decisions and further biases them against looking beyond physical and economic factors.

Pearce (2003) and Paton (2007) find that disaster preparedness initiatives fail when they have insufficient community involvement, an insight which is ubiquitous within the development sector. We posit that the effectiveness of DRM activities is likely to improve by accounting for the incentives that guide individual and community decision-making - i.e.., an approach which demonstrates how preparedness initiatives help a community achieve its human development and wellbeing goals. Complimentarily, an incorporation of human and social capital aspects is a notion central to modern development theory and practice, as well as natural resource management (Mostert et al., 2007).

Decisions relating to risk reduction activities tend to take a static and marginal approach, implicitly assuming that risk and socioeconomic conditions will not significantly change in the future or have 
feedback relationships with the initiative itself. This is particularly disconcerting considering increasing uncertainty regarding future climatic and socioeconomic trends. Similarly, detailed disaster impact assessments are typically undertaken in the months immediately following a disaster, and at best may consider impacts out to one year. While there is some notable exceptions in the macroeconomics field (Hallegatte, 2008; Okuyama and Chang, 2004; Rose and Lim, 2002), the majority of data on disaster impacts struggle to incorporate indirect or flow impacts of disasters.

An overarching approach to DRM which neglects human, social and environmental dynamics leads to decisions about managing disaster risk which can have unintended and/or negative consequences for both risk and development in the longer term via changes in land use, infrastructure and assets in hazard prone areas (Figure 5). At the 'risk reduction' phase of the disaster-risk management cycle, the classic example here is of the 'levee effect' (White, 1945; Burby, 2006). Levees are built to protect against flooding, yet they can alter and ultimately degrade the hydrology of the river system, eroding the environmental capital and provisioning services which support livelihoods, human wellbeing and actually absorb flood waters. At the same time, the people erroneously perceive that the levee provides a guarantee of safety, which induces development in the area. This alters the trajectory of development and increases exposure as more people and assets locate behind the levee. When the levee fails, as it is bound to do at some extreme point, the disaster is much bigger than would have been otherwise (Burby, 2006; Sendzimir et al., 2007).

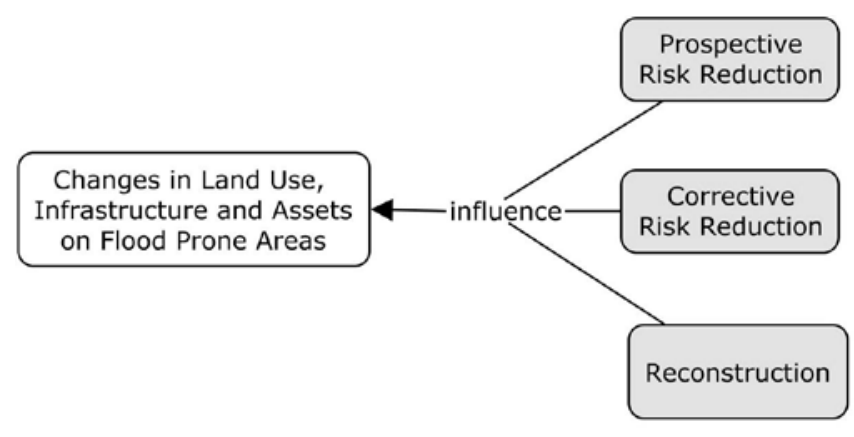

Figure 5: Disaster reduction and reconstruction decisions influence land use, infrastructure and assets in flood prone areas

Source: Authors.

At the same time that overall risk is increasing due to increases in exposure, there exists additional uncertainties in future socio-demographic, economic and climatic conditions. As discussed above, climate change is modifying intensity and frequency of hydrological hazards (Jongman et al., 2014; UNISDR, 2015). While we know this change in hazard intensity and frequency is occurring and will continue, the nature of local level change remains highly uncertain (IPCC, 2012). Often neither policy makers nor 
practitioners in DRM and elsewhere are experienced in making decisions under these types of uncertainty (Hallegatte et al., 2012). One significant uncertainty is around thresholds in social-ecological systems, which once crossed plunge the system into a new regime. Such socio-ecological system changes can happen very abruptly, persist strongly under the new regime, and may entail near or absolute irreversibility. The possibility of exceeding these types of system-altering thresholds is contributing to the impetus for applying the concept of resilience to disasters (Davoudi, 2012; O’Brien et al., 2012), as we explore below.

We have outlined a dynamic interconnection between disasters and prevailing development trends. This interconnection is widely and ever increasingly discussed, yet realizing it in practice to arrest growth in risk remains a challenge. The Hyogo Framework for Action (United Nations, 2005) laid out an ambitious program for addressing disaster risk and deliberately incorporated the interconnection between disasters and development into its priorities for action (UNISDR, 2015). However, a decade later the UNISDR (2015) has surmised that in the majority of countries the approach has been handled by environment ministries or emergency response agencies without the strategic capacity to truly influence change. DRM actions have been centred on the emergency response to hazard events, which continue to be viewed as exogenous to development.

3 Resilience of Community Well-being versus Resilience to Risk

There is growing recognition by scholars, policy-makers, and practitioners of the need for a dynamic and holistic approach which focusses on human wellbeing rather than hazards per se. This is compounded by the recognition that increasing interconnectedness and uncertainty are becoming critical features of the socio-ecological systems which support human life. It is against this backdrop that resilience has emerged as a popular concept in disasters. This is an unsurprising development since resilience has its roots in how systems respond to shocks.

\subsection{The evolution of disaster resilience}

The concept of 'resilience' has gained prominence in the disasters field in conjunction with a growing recognition of the problem of investing in ex-ante risk reduction and protection. Definitions have been proposed by physical and social scientists, multilateral donors, and practitioners (see table 1). We review and then build on these to conceptualize and define disaster resilience in a way which more explicitly addresses the prevailing challenges in the field and opportunities presented by the concept. 
Table 1: Definitions of disaster resilience

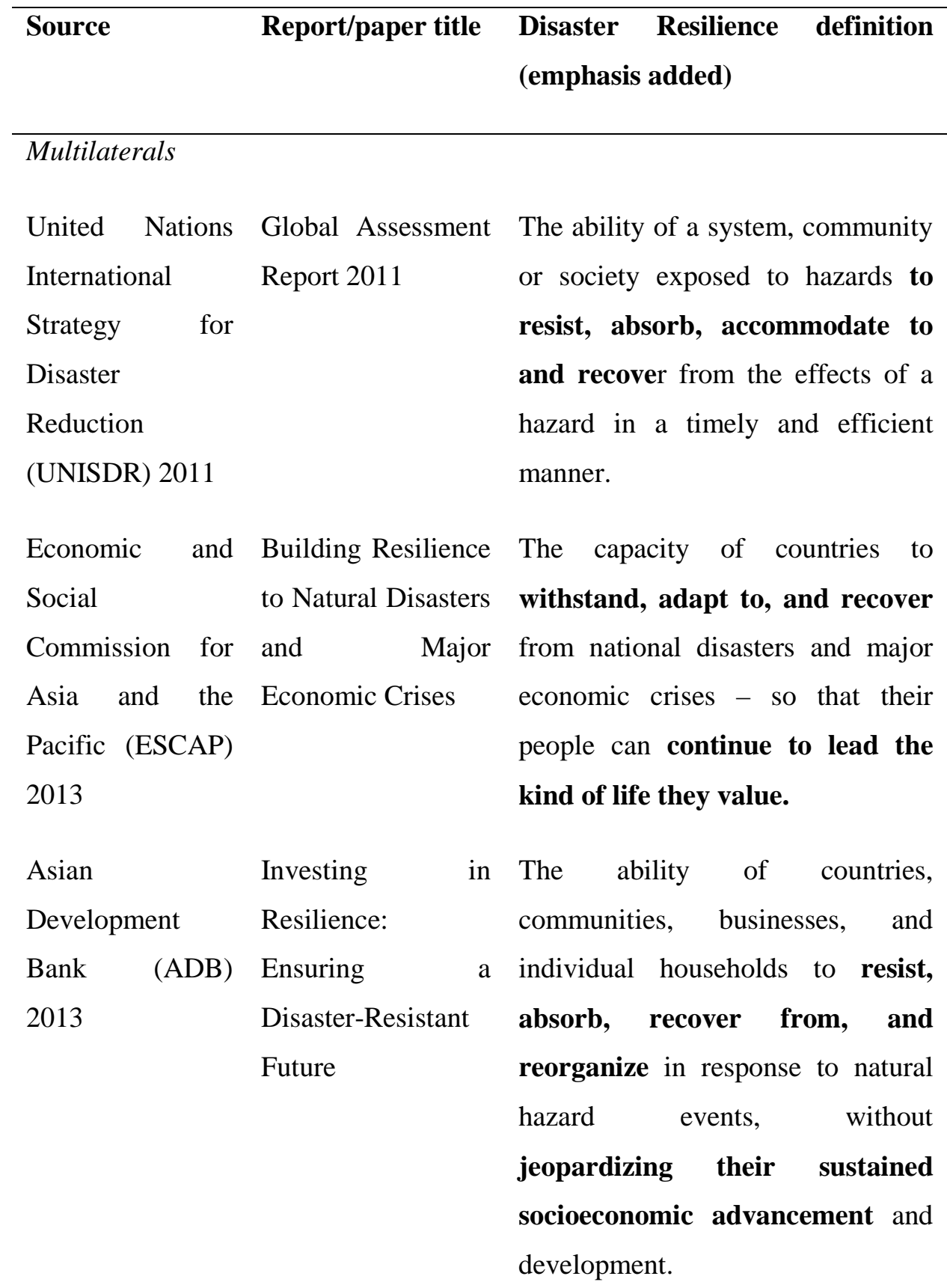

Development agencies and NGOs

Department for Defining Disaster The ability of countries, International Resilience: A DFID communities and households to Development Approach Paper manage change, by maintain or (UK) (DFID) transforming living standards in 


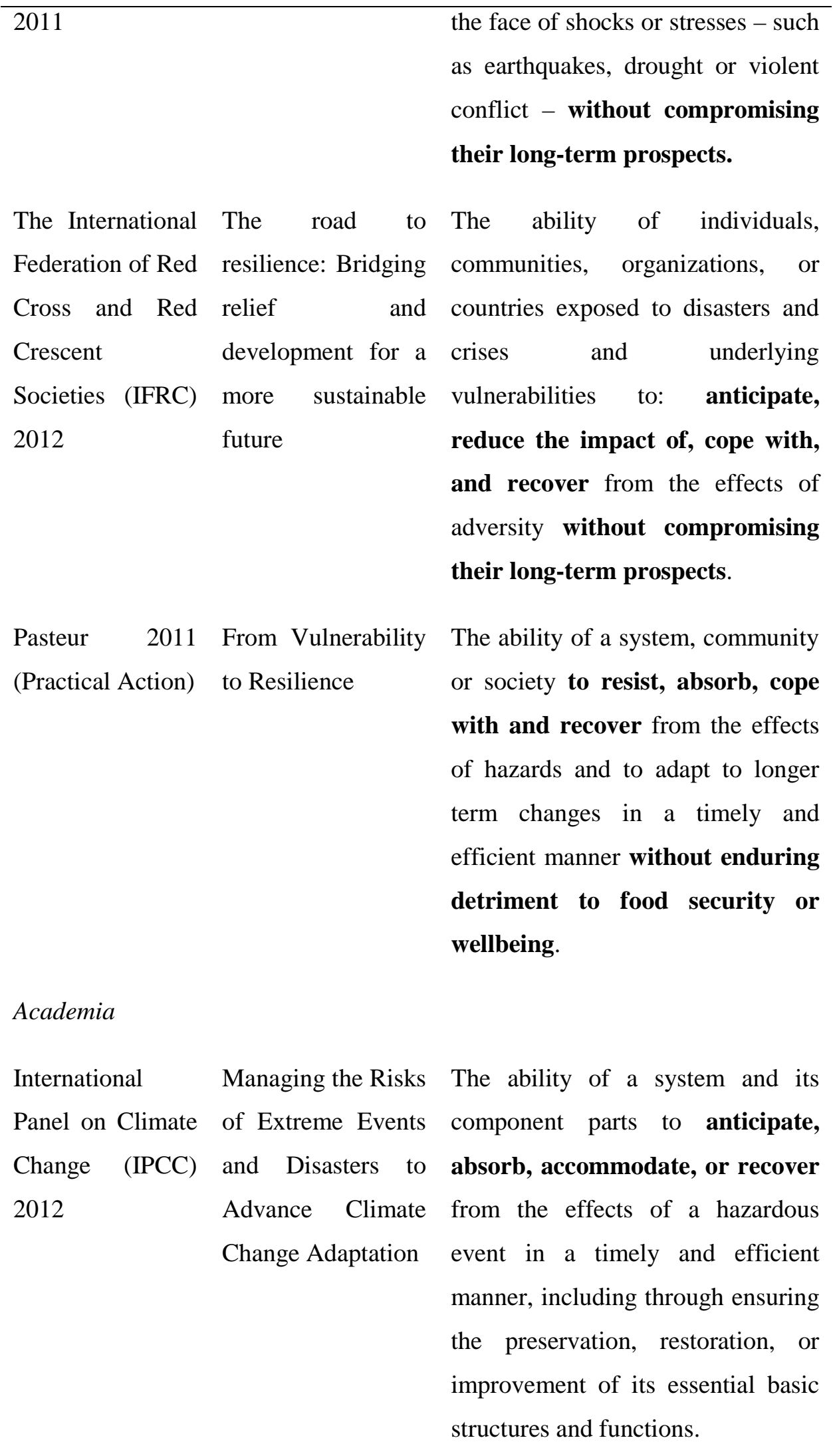




\begin{tabular}{|c|c|c|}
\hline $\begin{array}{l}\text { National } \\
\text { Research Council } \\
\text { (NRC) } 2012\end{array}$ & $\begin{array}{l}\text { Disaster Resilience: } \\
\text { A National } \\
\text { Imperative }\end{array}$ & $\begin{array}{l}\text { The ability to prepare and plan } \\
\text { for, absorb, recover from, and } \\
\text { more successfully adapt to adverse } \\
\text { events. }\end{array}$ \\
\hline Twigg 2009 & $\begin{array}{l}\text { Characteristics of a } \\
\text { Disaster Resilient } \\
\text { Community }\end{array}$ & $\begin{array}{l}\text { System or community resilience } \\
\text { can be understood as the capacity } \\
\text { to: }\end{array}$ \\
\hline & & $\begin{array}{l}\text {-anticipate, minimize and absorb } \\
\text { potential stresses or destructive } \\
\text { forces through adaptation or } \\
\text { resistance } \\
\text { •manage or maintain certain } \\
\text { basic functions and structures } \\
\text { during disastrous events } \\
\text {-recover or 'bounce back' after an } \\
\text { event }\end{array}$ \\
\hline Cutter et al. 2008 & $\begin{array}{l}\text { A place-based } \\
\text { model for } \\
\text { understanding } \\
\text { community } \\
\text { resilience to natural } \\
\text { disasters }\end{array}$ & $\begin{array}{l}\text { Resilience is the ability of a social } \\
\text { system to respond and recover } \\
\text { from disasters and includes those } \\
\text { inherent conditions that allow the } \\
\text { system to absorb impacts and } \\
\text { cope with an event, as well as post- } \\
\text { event, adaptive processes that } \\
\text { facilitate the ability of the social } \\
\text { system to re-organize, change, } \\
\text { and learn in response to a threat. }\end{array}$ \\
\hline
\end{tabular}

All definitions listed in Table 1 refer to the 'ability' or 'capacity' to withstand and recover (UNISDR, 2011; ESCAP, 2013; ADB, 2013; DFID, 2011; IFRC, 2012; Pasteur, 2011; IPCC, 2012; NRC, 2012; Twigg, 2009; Cutter et al., 2008). There is a distinction between definitions that tend to assume that the 
current level of development is acceptable and those that assume development is, or ought to be, on an upwards trajectory. As an example of the latter, DFID (2011) includes 'by maintain or transforming living standards' thereby suggesting that a key component of resilience is ensuring that disasters do not halt or reverse positive trends in development outcomes.

The definitions have many common elements and reflect much of the thinking outlined in this paper. Many of the definitions recognize the importance of DRM, in particular including aspects of risk reduction shown in the use of the words 'plan', 'anticipate' and 'adapt to'. Many also include mention of development opportunities. For instance, the definition by the Asian Development Bank (ADB 2013), states that disaster resilience is '[t]he ability of countries, communities, businesses, and individual households to resist, absorb, recover from, and reorganize in response to natural hazard events, without jeopardizing their sustained socioeconomic advancement and development ' (emphasis added). Similarly DFID (2011) and IFRC (2012) mention 'without compromising their long-term prospects' at the end of their definitions; Pasteur (2011) (Practical Action) ends with the phrase 'without enduring detriment to food security or wellbeing.' These definitions all hint at the fact that disasters can impede development or wellbeing over time.

Our reading of these definitions has identified a number of strides already taken and also a number of opportunities for enhancing the significance of resilience as a concept in the disasters discourse and corresponding development policy. Firstly, we propose that the importance of the long-term interconnection between disaster risk and development - which drives wellbeing (the ultimate purpose of DRM and development) be brought to the forefront of definitions of disaster resilience. Secondly, the $e x$ post aspects of response and 'bouncing back' are typically well covered, and this should be more fully complemented by an emphasis on ex-ante action in the form of prospective risk reduction (avoiding risk creation via development decisions), and corrective risk reduction (reducing risk to existing assets).

\subsection{Defining development-centred disaster resilience}

Taking the existing definitions and current thinking outlined above forward, we propose a novel conceptualization of disaster resilience that (1) explicitly emphasizes development opportunity, as this is arguably the reason disaster resilience is desirable, (2) sees disaster resilience embedded in complex adaptive systems, (3) identifies disaster resilience as being able to survive events, thrive in the face of uncertain future events and continue to strive towards new opportunities in the face of changing disaster risks, and (4) includes the capacity of the system to transform/reorganize in the face of changing social, economic, and environmental trends. These elements of a more holistic framework appear in a number of 
the definitions mentioned above. Bringing these out more explicitly, we suggest a broad-based working conceptualization of disaster resilience as:

'The ability of a system, community or society to pursue its social, ecological and economic development objectives, while managing its disaster risk over time in a mutually reinforcing way.'

The conceptualization of disaster resilience presented here is built on the assertion that the overarching objective of both development and DRM is to promote the wellbeing of people. We argue that by conceptualizing disaster resilience in this way, the concept's usefulness in bridging the DRM and development fields is realized. Furthermore, this approach is founded in systems thinking, which is critical in an increasingly interdependent world. If resilience can explicitly emphasize these aspects, then it becomes more than just a passing buzzword.

We contend that communities and societies are complex adaptive systems; this means they are able to learn and change and operate in an environment that is changing (Levin, 1998; Lansing, 2003; Holland, 2006). This also means that the community and society (depending on the scale in question) faces risks and totally eliminating these risks is neither possible nor desirable. As they are dynamic and the environment is changing, over time the community's wellbeing and development opportunities will likely change. To continuously grow and develop in the face of risk implies the need for a risk management process (identifying, mitigating, preparing for and responding to the risk). That is, communities or societies that are always pursuing development opportunities must do so in a way that balances the risks, if they hope to continue to pursue their objectives and thrive. Thus we do not define resilience as doing the steps of DRM (see Figure 4) (albeit this should be a part of enhancing disaster resilience capabilities), but rather as a concept inherently linked to development and wellbeing.

Enhancing disaster resilience both reduces the incidence and severity of the hazard, and fosters capabilities within societies so that they are less disturbed by disasters when they do occur. While economic growth and development can be a driver of risk by increasing the value exposed to a hazard, economic growth and development can also increase the sources of resilience by increasing the capacity to avoid risk creation in the first place, invest in protection, undertake preparedness measures, enable better coping strategies and afford recovery and reconstruction.

\section{Development-centred disaster resilience in action}

Building on our research and definition of disaster resilience, we now present a simplified conceptual framework of disaster resilience which explicitly focuses on the system interactions between disaster risk 
(both direct and indirect), DRM practices, and development (holistically understood). This framework has been developed within collaborative work in flood prone communities, hence it is currently structured around the community level and the specifics of flood risk; it is currently called the Flood Resilience (FLORES) Framework. However the framework could be generalized to different scales and hazards.

This systems perspective is a way to conceptualize and analyse the dynamic interconnections which result in human development and wellbeing outcomes. Because this framework is more holistic and explicitly aims to take account of interdependencies, it should be executed by decision-makers, or ideally a group of stakeholders, with a coordinated mission and the capacity to affect real change in the drivers of disaster risk - e.g., infrastructure, land use planning, environmental policies, economic growth policies, to name a few.

A key to systems thinking is looking at relationships and connections between the parts in the system. From a systems perspective, a better understanding of the channels and the relationships that govern development and disaster risk has the potential to provide insight into effective 'buffer zones', 'leverage points' and other flow control measures that can greatly enhance the sources of resilience ex-ante, which effect ex post resilient outcomes. The systems perspective of resilience is cyclical and dynamic, encompassing the feedback loops and interconnections demonstrated in Figure 6.

Figure 6 shows a conceptual representation of our disaster resilience framework, as applied to the community level in a flood-risk area. It depicts the complex community system linking development/wellbeing, risk (direct and indirect), and DRM capabilities. A systems approach is particularly useful here, because it helps to keep focus on how policies that affect one function interact with the others, which then affect the overall functioning of the community. For example, a policy that is meant to enhance resilience by increasing the number of evacuation routes could encroach on the marshlands that provide natural drainage systems - a policy designed to reduce erosion. 


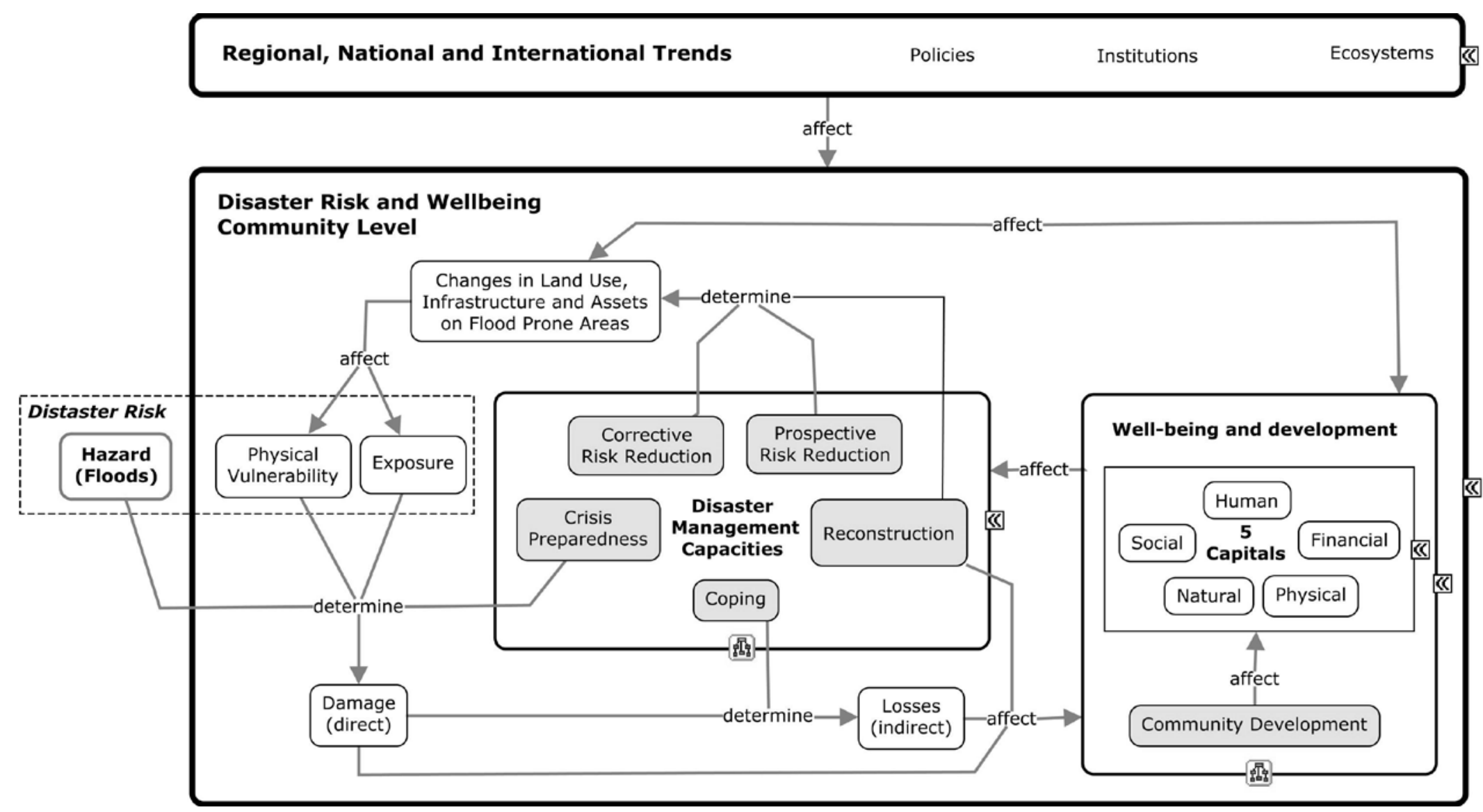

Figure 6: FLORES Framework. The diagram is built using the Concept Map method (Novak \& Cañas, 2006). Source:

Authors. 
The figure shows some (but by no means all) of the relationships within the complex system linking development and wellbeing, risk (direct and indirect), and the traditional DRM cycle. Starting with the accepted understanding of disaster risk, we show the elements of hazard, exposure and vulnerability. The bottom half of the framework shows how disasters and ex-ante disaster response jointly determine the impact of a disaster on development. We see how the elements of risk (hazard, exposure and vulnerability) coupled with crisis response actions jointly determine the risk of direct damage. This direct damage influences development via, for example, direct damage to productive assets. The type of coping mechanisms employed within the system influence the way in which the direct damage transforms losses (also known as indirect damage). Losses also impact on development. The link showing that development/wellbeing impacts DRM represents the relationship between resources within the system and the capacity and type of DRM which is able to be undertaken. Generally speaking communities with higher asset endowments tend to have higher capacity to engage in DRM. However it should be noted that the type of capital held by the community will impact the type of DRM that is possible.

Moving from right to left along the top half of Figure 6 we see the way in which development and disaster risk reduction activities jointly feedback into disaster risk. This sketches out the 'development impacts disasters' argument together with the recognition that both prospective and corrective risk reduction decisions can have long-term (and sometimes unintended) consequences. These interactions happen via land use, infrastructure and asset location decisions. Development and risk reduction decisions influence land use, infrastructure and asset location, which in turn influences exposure and physical vulnerability. Trends at the national, regional, and international level also have significant impacts on the functioning of systems, such as communities, at lower levels; hence these must be considered in the broader context and are represented at the top of the figure.

The purpose of the FLORES framework is to allow stakeholders to systematically explore the way disaster risk impacts development and wellbeing, the way development decisions (including land use, environmental and economic growth policies) might increase or mitigate disaster risk, and the way DRM initiatives can impact development in the longer-term. Early versions of the framework were shared with DRM and development practitioners from our partner organisations, who contributed much to this version. Overwhelmingly the response from practitioners is that the framework realistically maps what they intuitively know already; this is as it should be. By sketching out intuitive but disparate knowledge in a systematic way, the framework provides a foundation from which to engage in deeper understanding of the drivers of disaster risk and development, as well as intervention options. 
We are applying this framework in a number of communities in developing countries. At the assessment phase the framework is being utilized in multi-stakeholder workshops to bring stakeholders from different levels (community through to national) together to: 1) develop a shared understanding of the drivers of disaster risk and development in their area, and 2) jointly identify intervention options which will support both risk reduction and community development/wellbeing. Further uses for the framework are under development, however we anticipate it to be used in a number of other ways throughout the project cycle. At the prioritization phase, the framework provides a structured way of identifying indirect and intangible impacts of interventions, which may enhance or diminish their desirability for different groups. At the intervention phase, use of the framework enables practitioners and stakeholders to carefully manage impacts so that inadvertent risk creation or erosion of development potential is avoided, and risk reduction and development potential enhanced. Finally at the evaluation phase the indirect and intangible impacts of the intervention can be more readily identified. Lessons from this ongoing work will also be used to empirically explore the key relationships driving risk and development.

\section{Conclusion}

Disaster risk is on the rise and currently countries, communities, NGOs, the private sector, and the international community are heavily engaged in debate regarding means to tackle risk effectively. The core of the failure to arrest the growth in disaster risk - as epitomized by the very limited success of the risk reduction component of the HFA (United Nations, 2005), has less to do with the HFA itself and more to do with the practical constraints on ex-ante DRM coupled with substantial myopia towards disaster risk. In the vast majority of countries, reducing risk has been given extremely low priority and thus relegated to a drastically under-funded add-on to the remit of the emergency management sector, rather than a shift in development policy (UNISDR, 2015). This issue will be magnified under changes in hazard frequency and severity, as well as social vulnerability, under climate change.

We would stress that we are not disparaging the humanitarian sector or government emergency management authorities, who have saved countless lives on limited budgets. Similarly we are not disparaging governments, multilaterals, or development NGOs who by and large have undertaken significant efforts to 'mainstream' disaster risk into their work. This work is essential, yet has been demonstrated to be insufficient. The challenges to integrating DRM and development policy and initiatives, in a way which effectively takes account of the interactions outlined here, are deep seated. The segregation between development and disaster fields was established in centuries past and remains seated in the institutional structures which persist today. 
Resilience, once properly defined and operationalized, provides a framework by which the development and risk management objectives of a community may be unified. Overall we find that disaster risk is inextricably tied to development - both driven by development and impacting on development. While both promoters of development and DRM intend to improve the well-being of households and communities, both are prone to myopic perspectives that reduce their effectiveness. The concept of resilience has the potential to engender a meaningful shift in both development and disaster policy (insofar as they currently remain operationally separate). The shift is subtle - rather than focusing on the resilience to risk we propose that both fields must focus on the resilience of community well-being.

However this shift in understanding and resulting change of policy and practice will only be possible if the systems thinking embodied in resilience comes to the fore. If resilience becomes a rebranding of 'DRM done well' the creation of risk will not be adequately averted because it will not remedy the challenges inherent in our current approach to disaster risk. Here we find significant agreement with the UNISDR (2015) who point out that the need to move thinking from disaster resilience to resilient development.

Our contribution to this endeavour is to propose a conceptualization of resilience based on a systems approach that moves beyond the narrow and static conceptualizations that have characterized the field to date. We first present a development-centred definition of disaster resilience, and secondly map out a systems framework which highlights the dynamic interconnections between development, disasters and DRM. The functioning of this system can result in multiple development and disaster risk outcomes in the long-term.

This systems thinking approach to disaster resilience is being utilized in a number of case studies in communities in Peru and Nepal. The framework is still being developed in conjunction with practitioner partners, however early results indicate its significant usefulness in conceptualizing the complexity of the relationship between disasters and development. The relationships outlined in the framework are not revolutionary and are in fact quite intuitive. What is useful to practitioners is having a way to visually organize the context in which they are working. The FLORES system diagram provides a risk assessment process that allows a holistic assessment of risks, and how risks are related to help avoid overlooking the less obvious risks present in the system. Being able to plan for both DRM and community development is a significant progress, allowing communities to identify constraints (where an asset is limited or restricted), where are the choke points are, where many critical flows can be log jammed, and where are the leverage points for change. By taking a systematic approach to resilience the full impact of disasters is better understood, and avenues for leveraging an event into transformational change are realized. 
We do not underestimate the challenges associated with the shift in thinking and associated change in policy and practice that we propose. Navigating the tensions associated with any coordinated approach is a significant impediment to a systems approach being adopted and maintained over time. It is for this reason that we are conducting this research in collaboration with the NGO sector. Similarly, this paper represents an opening discussion with the academy in order to build on the academic process as the work continues. 


\section{References}

Adger, W. N. and Brooks, N. (2003) 'Does global environmental change cause vulnerability to disaster?' in Natural Disaster and Development in a Globalising World, ed. M. Pelling, Routledge.

Adger, W. N., Hughes, T. P., Folke, C., Carpenter, S. R. and Rockström, J. (2005) 'Social-Ecological Resilience to Coastal Disasters’'Science 309(5737): 1036-1039.

Anttila-Hughes, J. \& Hsiang, S. (2013) Disinvestment, and Death: Economic and Human Losses Following Environmental Disaster (February 18, 2013). Available at SSRN: $\underline{\text { http://ssrn.com/abstract=2220501 or http://dx.doi.org/10.2139/ssrn.2220501. }}$

Asian Development Bank (ADB) (2013) Investing in resilience: Ensuring a disaster-resistant future, Asian Development Bank, Manila.

Banholzer, S., Kossin, J. and Donner, S. (2014) 'The Impact of Climate Change on Natural Disasters', chap. 2 in Reducing Disaster: Early Warning Systems for Climate Change, eds. Z. Zommers and A. Singh, Springer.

Benson, C. and Clay, E. (2004) Understanding the economic and financial impact of natural disasters, The International Bank for Reconstruction and Development \& The World Bank, Washington D.C.

Benson, C. and Twigg, J. (2004) Measuring mitigation: methodologies for assessing natural hazard risks and the net benefits of mitigation, International Federation of Red Cross and Red Crescent Societies (IFRC), ProVention Consortium, Geneva.

Berhanu, W. (2011) 'Recurrent shocks, poverty traps and the degradation of pastoralists' social capital in Southern Ethiopia', AfJRE 6(1): 1-15.

Bernard, K. and Cook, S. (2012) Tourism Investment Choices and Flood Risk: illustrative case study on Denarau Island Resort in Fiji, Background Paper prepared for the Global Assessment Report on Disaster Risk Reduction 2013, UNISDR, Geneva, Switzerland.

Braun, B. and Assheuer, T. (2011) 'Floods in megacity environments: vulnerability and coping strategies of slum dwellers in Dhaka/Bangladesh’ Natural Hazards 58: 771-787.

Bryceson, D. (2000) 'Disappearing Peasantries? Rural Labour Redundancy in the Neo-Liberal Era and Beyond', in Disappearing Peasantries? eds. D. Bryceson, T. Kay and J. Mooij, Practical Action, pp. 30405. 
Bubeck, P., Botzen, W., Kreibich, H. and Aerts, J. (2012) 'Long-term development and effectiveness of private flood mitigation measures: An analysis for the German part of the river Rhine', Natural Hazards and Earth System Sciences 12: 3507-3518.

Bull-Kamanga, L, Diagne, K., Lavell, A., Leon, E., Lerise, F., MacGregor, H., Maskrey, A., Meshack, M., Pelling, M., Reid, H., Satterthwaite, D., Songsore, J., Westgate, K. and Yitambe, A. (2003) “From everyday hazards to disasters: the accumulation of risk in urban areas” Environment and Urbanization 15(1): 193-203.

Burby, R. (2006) 'Hurricane Katrina and the Paradoxes of Government Disaster Policy: Bringing About Wise Governmental Decisions for Hazardous Areas', Annals of the American Academy of Political and Social Science 604: 171-191.

Cardona, O. (2003) 'The Need for Rethinking the Concepts of Vulnerability and Risk from a Holistic Perspective: A Necessary Review and Criticism for Effective Risk Management' Chapter 3 in Mapping Vulnerability: Disasters, Development and People, eds.: G. Bankoff, G. Frerks, D. Hilhorst, Earthscan Publishers, London.

Cavallo, E. and Noy, I. (2009) The Economics of Natural Disasters: A Survey, IDB Working Paper No. 35. Available at SSRN: http://ssrn.com/abstract=1817217 or http://dx.doi.org/10.2139/ssrn.1817217

Charveriat, C. (2000) Natural Disasters in Latin America and the Caribbean: An Overview of Risk, Working Paper No. 434. Research Department, Inter-American Development Bank, Washington, D.C.

CRED (2015) The Human Cost of Natural Disasters 2015: A global perspective, Centre for Research on Epidemiology of Disasters, Université catholique de Louvain, Brussels, Belgium.

Cutter, S., Emrich, C., Mitchell, J., Boruff, B., Gall, M., Schmidtlein, M., Burton, C. \& Melton, G. (2006) 'The Long Road Home: Race, Class, and Recovery from Hurricane Katrina', Environment: Science and Policy for Sustainable Development 48(2): 8-20.

Cutter, S., Barnes, L., Berry, M., Burton, C., Evans, E., Tate, E. and Webb, J. (2008) 'A place-based model for understanding community resilience to natural disasters', Global Environmental Change 18(4): 598-606.

Davoudi, S. (2012) 'Resilience: A Bridging Concept or a Dead End?', Planning Theory and Practice 13(2): 299-307. 
de Sherbinin, A., Schiller, A. and Pulsipher, A. (2007) 'The vulnerability of global cities to climate hazards’ Enviornment and Urbanisation 19(1): 39-64.

DFID (1999) Sustainable Livelihoods Guidance Sheets, Department of International Development, United Kingdom, http://www.eldis.org/vfile/upload/1/document/0901/section2.pdf

DFID (2011) Defining Disaster Resilience: A DFID Approach Paper, Department of International Development, United

Kingdom, https://www.gov.uk/government/uploads/system/uploads/attachment data/file/186874/defining -disaster-resilience-approach-paper.pdf

ECLAC (2003) Handbook for Estimating the Socio-Economic and Environmental Effects of Disasters, Mexico City, United Nations Economic Commission for Latin America and the Caribbean, http://www.preventionweb.net/files/1099_eclachandbook.pdf

ESCAP (2013) Building Resilience to Natural Disasters and Major Economic Crises, United Nations Economic and Social Commission for Asia and the Pacific, http://www.unescap.org/sites/default/files/ThemeStudy2013-full2.pdf

Fafchamps, M. and Lund, S. (2003) 'Risk-sharing networks in rural Philippines', Journal of Development Economics 71(2): 261-287.

Fernandez, R. and Sanahuj, H. (2012) Linkages between population dynamics, urbanization processes and disaster risk: A regional vision of Latin America, UNISDR AM, UN-HABITAT and UNFPA, http://www.unisdr.org/we/inform/publications/31104

Foresight (2012) Reducing Risks of Future Disasters: Priorities for Decision Makers, Final Project Report, The Government Office for Science, London.

Garschagen, M. and Romero-Lankao, P. (2015) 'Exploring the relationships between urbanization trends and climate change vulnerability' Climatic Change 133(1): 37-52.

Gencer, E. A. (2012) 'Natural Disasters, Urban Vulnerability, and Risk Management: A Theoretical Overview', chap. 2 in The Interplay between Urban Development, Vulnerability, and Risk Management, SpringerBriefs Volume 7, pp. 7-43.

Gerulis-Darcy, M. (2013) Implications of the Global Political Economy on Vulnerability to Disaster: The Case of Long-Term Structural Adjustment Policies in Nicaragua, Background Paper prepared for the Global Assessment Report on Disaster Risk Reduction 2013, UNISDR, Geneva, Switzerland. 
Guha-Sapir, D., Below, R. and Hoyois, Ph, EM-DAT (n.d.), International Disaster Database, http://www.emdat.be Université Catholique de Louvain, Brussels, Belgium.

Hallegatte, S. (2008) 'An Adaptive Regional Input-Output Model and its Application to the Assessment of the Economic Cost of Katrina', Risk Analysis, 28(3):779-99

Hallegatte, S. (2011) How economic growth and rational decisions can make disaster losses grow faster than wealth, World Bank, Policy Research Working Paper no. 5617, http://wwwwds.worldbank.org/external/default/WDSContentServer/IW3P/IB/2012/04/10/000158349 20120410132 621/Rendered/PDF/WPS5617.pdf .

Hallegatte, S., Shan, A., Lempert, R., Brown, C. and Gill, S. (2012) Investment Decision Making Under Deep Uncertainty, World Bank Policy Research Working Paper \# 6193, http://papers.ssrn.com/sol3/papers.cfm?abstract_id=2143067 [accessed 4 April 2015]

Heine, R. and Pinter, N. (2012) 'Levee effects upon flood levels: an empirical assessment’ Hydrological Processes, 26(21): 3225-3240.

Heltberg, R., Hossain, N. and Reva, A. eds. (2012) Living Through Crises: How the Food, Fuel, and Financial Shocks Affect the Poor, World Bank, Washington D.C.

Hochrainer, S. (2009) Assessing the Macroeconomic Impacts of Natural Disasters: Are there any? World Bank Research Paper \# 4968, http://papers.ssrn.com/sol3/papers.cfm?abstract_id=1427628

Hochrainer-Stigler, S., Patnaik, U., Kull, D., Singh, P. and Wajih, S. (2011) 'Disaster financing and poverty traps for poor households: Realities in Northern India' IJMED - International Journal of Mass Emergencies and Disasters 29(1):57-82.

Holland, J. H. (2006). Studying complex adaptive systems. Journal of Systems Science and Complexity, 19(1), 1-8.

IFRC (2012) Understanding community resilience and program factors that strengthen them: A comprehensive study of Red Cross Red Crescent Societies tsunami operation, International Federation of Red Cross and Red Crescent Societies, June 2012, https://www.ifrc.org/PageFiles/96984/Final_Synthesis_Characteristics Lessons Tsunami.pdf

IPCC (2012) Managing the Risks of Extreme Events and Disasters to Advance Climate Change Adaptation, A Special Report of Working Groups I and II of the Intergovernmental Panel on Climate Change [Field, C.B., V. Barros, T.F. Stocker, D. Qin, D.J. Dokken, K.L. Ebi, M.D. Mastrandrea, K.J. 
Mach, G.-K. Plattner, S.K. Allen, M. Tignor, and P.M. Midgley (eds.)]. Cambridge University Press, Cambridge, UK, and New York, NY, USA.

Jongman, B., Hochrainer-Stigler, S., Feyen, L., Aerts, J., Mecher, R., Botzen, W., Bouwer, L., Pflug, G., Rodrigo, R. and Ward, P. (2014) 'Increasing stress on disaster risk finance due to large floods', Nature Climate Change 4: 264-268.

Kellenberg, D., and Mobarak, A. (2008) 'Does rising income increase or decrease damage risk from natural disasters?’ Journal of Urban Economics 63(3): 788-802.

Kellett, J. and Caravani, A. (2013) Financing disaster risk reduction: A 20-year story of international aid, ODI and the Global Facility for Disaster Reduction and Recovery at the World Bank, London / Washington.

Kreibich, H. and Thieken, A. (2007) 'Coping with floods in the city of Dresden, Germany', Natural Hazards DOI 10.1007/s11069-007-9200-8.

Kunreuther, H., Meyer R. and Michel-Kerjan, E. (2013) 'Overcoming Decision Biases to Reduce Losses from Natural Catastrophes’ in E. Shafir (ed.), Behavioral Foundations of Policy, Princeton University Press, New Jersey.

Lansing, J. S. (2003). Complex adaptive systems. Annual review of anthropology, 183-204.

Lavell, A. and Maskrey, A. 'The Future of Disaster Risk Management', Environmental Hazards 13(4).

Levin, S. A. (1998). Ecosystems and the biosphere as complex adaptive systems. Ecosystems, 1(5), 431436.

Linnerooth-Bayer, J. (2008). 'Non-insurance mechanisms for managing climate-related risks', Mechanisms to manage financial risks from direct impacts of climate change in developing countries. Technical paper. FCCC/TP/2008/9, United Nations Office at Geneva, Geneva, http://unfccc.int/4159.php

Mechler, R. (2004) Natural Disaster Risk Management and Financing Disaster Losses in Developing Countries, Verlag für Versicherungswirtschaft, Karlsruhe.

Mechler, R. and Bouwer, L. (2014) 'Understanding trends and projections of disaster losses and climate change: is vulnerability the missing link?', Climate Change, DOI: 10.1007/s10584-014-1141-0.

Mechler, R., Czajkowski, J., Kunreuther, H., Michel-Kerjan, E., Wouter, B., Keating, A., McQuistan, C., Cooper, N., O’Donnell, I. (2014) Making Communities More Flood Resilient: The Role of Cost Benefit 
Analysis and Other Decision-Support Tools in Disaster Risk Reduction, Zurich Flood Resilience Alliance, http://opim.wharton.upenn.edu/risk/library/ZAlliance-decisiontools-WP.pdf [accessed 4 April 2015]

Miller, S., Muir-Wood, R. and Boissonnade, A. (2008) 'An Exploration of Trends in Normalized Weather Related Catastrophe Losses' in Climate Extremes and Society, eds. H. F. Diaz and R. J. Murnane. Cambridge, UK, Cambridge University Press, 225-247.

Mochizuki, J., Mechler, R., Hochrainer-Stigler, S., Keating, A., Williges, K. (2015) 'Revisiting the 'disaster and development' debate - Toward a broader understanding of macroeconomic risk and resilience’ Climate Risk Management, 3: 39-54.

Morris, S., Neidecker-Gonzales, O., Carletto, C., Munguia, M., Medina, J. and Wodon, Q. (2002) 'Hurricane Mitch and the livelihoods of the rural poor in Honduras', World Development 30(1): 49-60.

Mostert, E., Pahl-Wostl, C., Rees, Y., Searle, B., Tàbara, D. and Tippett, J. (2007) 'Social learning in European river-basin management: barriers and fostering mechanisms from 10 river basins', Ecology and Society 12(1): 19.

National Research Council (NRC) (2012) Disaster Resilience: A National Imperative. The National Academies Press, Washington, D.C.

Neumayer, E. and Plümper, T., (2007) 'The Gendered Nature of Natural Disasters: The Impact of Catastrophic Events on the Gender Gap in Life Expectancy, 1981-2002' Annals of the Association of American Geographers 97(3): 566 http://www.lse.ac.uk/geographyAndEnvironment/whosWho/profiles/neumayer/pdf/Article\%20in\%20 Annals\%20(natural\%20disasters).pdf [accessed 4 April 2015]

Novak, J. D., and Cañas, A. J. (2006). The theory underlying concept maps and how to construct them. Florida Institute for Human and Machine Cognition, 1.

Noy, I. (2009) 'The macroeconomic consequences of disasters', Journal of Development Economics 88(2): 221-231.

O’Brien, K., Pelling, M., Patwardhan, A., Hallegatte, S., Maskrey, A., Oki, T., Oswald-Spring, U., Wilbanks, T. \& Yanda, Z. (2012) 'Toward a sustainable and resilient future', in: Managing the Risks of Extreme Events and Disasters to Advance Climate Change Adaptation [Field, C.B., V. Barros, T.F. Stocker, D. Qin, D.J. Dokken, K.L. Ebi, M.D. Mastrandrea, K.J. Mach, G.-K. Plattner, S.K. Allen, M. 
Tignor, and P.M. Midgley (eds.)]. A Special Report of Working Groups I and II of the Intergovernmental Panel on Climate Change (IPCC). Cambridge University Press, Cambridge, UK, and New York, NY, USA, pp. 437-486.

Okuyama, Y. (2003) ‘Economics of natural disasters: A critical review’, Res. Pap. 12:20-22.

Okuyama, Y. and Chang, S. (eds.) (2004) Modeling Spatial and Economic Impacts of Disasters, Heidelberg, Springer.

Otero, R. and Marti, R. (1995) 'The impacts of natural disasters on developing economies: implications for the international development and disaster community', in: , M. Munasinghe and C. Clarke (eds.), Disaster Prevention for Sustainable Development: Economic and Policy Issues, The International Bank for Reconstruction and Development/The World Bank, Washington, pp: 11-40.

Pasteur, K. (2011) From Vulnerability to Resilience, Practical Action Publishing, Rugby.

Paton, D. (2007) 'Preparing for natural hazards: the role of community trust' Disaster Prevention and Management: An International Journal 16(3): 370-379.

Pearce, L. (2003) 'Disaster management and community planning, and public participation: how to achieve sustainable hazard mitigation', Natural Hazards 28(2-3): 211-228.

Raddatz, C. (2007) 'Are external shocks responsible for the instability of output in low-income countries?' Journal of Development Economics 84: 155-187.

Rose, A. and Lim. D. (2002) 'Business interruption losses from natural hazards: conceptual and methodological issues in the case of the Northridge earthquake' Global Environmental Change Part B: Environmental Hazards 4(1): 1-14.

Schipper, L. and Pelling, M. (2006) 'Disaster risk, climate change and international development: scope for, and challenges to, integration', Disasters 30(1): 19-38.

Sendzimir, J., Magnuszewski, P., Balogh, P., and Vari, A. (2007). Anticipatory modeling of biocomplexity in the Tisza River Basin: First steps to establish a participatory adaptive framework. Environmental Modelling \& Software, 22(5), 599-609.

Sendzimir, J., Magnuszewski, P., Flachner, Z., Balogh, P., Molnar, G., Sarvari, A., and Nagy, Z. (2008). Assessing the resilience of a river management regime: informal learning in a shadow network in the Tisza River Basin. Ecology and Society, 13(1), 11. 
Townsend, R. (1994) ‘Risk and insurance in village India’, Econometrica 62:539-591.

Twigg, J. (2009) Characteristics of a Disaster Resilient Community, http://community.eldis.org/.59e907ee/Characteristics2EDITION.pdf

UNISDR (2009) Terminology http://www.unisdr.org/we/inform/terminology

UNISDR (2011) Global Assessment Report on Disaster Risk Reduction, United Nations International Strategy for Disaster Reduction, Geneva.

UNISDR (2013) From Shared Risk to Shared Value -The Business Case for Disaster Risk Reduction, United Nations Office for Disaster Risk Reduction, Geneva.

UNISDR (2015) Global Assessment Report on Disaster Risk Reduction - Making Development Sustainable: The Future of Disaster Risk Management, United Nations Office for Disaster Risk Reduction, Geneva, http://www.preventionweb.net/english/hyogo/gar/2015/en/gar-pdf/GAR2015 EN.pdf [accessed 4 April 2015]

United Nations (2005) Hyogo Framework for Action 2005-2015: Building the Resilience of Nations and Communities to Disasters, 22 January 2005, A/CONF.206/6, available at: http://www.refworld.org/docid/42b98a704.html [accessed 30 March 2015]

United Nations (2014) World Urbanization Prospects: The 2014 Revision, United Nations Department of Economic and Social Affairs, Population Division (ST/ESA/SER.A/352).

United Nations (2015) Sendai Framework for Disaster Risk Reduction 2015-2030, 18 march 2015, A/CONF.224/CRP.1, $\quad$ available at: $\quad$ http://www.wcdrr.org/uploads/Sendai Framework for Disaster Risk Reduction 2015-2030.pdf [accessed 30 march 2015]

van Aalst, M. (2006) 'The impacts of climate change on the risk of natural disasters' Disasters 30(1): 518.

van Aalst, M., Kellett, J., Pichon, F. and Mitchell, T. (May 2013) 'Incentives in Disaster Risk Management and Humanitarian Response,' Background note for World Development Report 2014, at http://siteresources.worldbank.org/EXTNWDR2013/Resources/8258024-1352909193861/89369351356011448215/8986901-

1380568255405/WDR14_bn_Incentives_in_disaster_risk_management_vanAalst.pdf (retrieved 28 March 2015). 
Wamsler, C. (2004) 'Managing Urban Risk: Perceptions of Housing and Planning as a Tool for Reducing Disaster Risk’ Global Built Environmental Review (GBER) 4(2): 11-28.

White G. (1945) Human Adjustment to Floods. Department of Geography Research Paper no. 29, The University of Chicago, Chicago.

Zubair, L., Ralapanawe, V., Tennakoon, U., Yahiya, Z. and Perera, R. (2006) 'Natural Disaster Risks in Sri Lanka: Mapping Hazards and Risk Hotspots’ Chapter 4 in Natural Disaster Hotspots: Case Studies, eds. M. Arnold, R. S. Chen, U. Deichmann, M. Dilley, A. L. Lerner-Lam, R. E. Pullen and Z. Trohanis, The World Bank Hazard Management Unit, Washington, D. C. http://siteresources.worldbank.org/INTDISMGMT/Resources/0821363328.pdf?resourceurlname=0821 363328.p\$ [accessed 4 April 2015] 